British \& Irish Botany 2(3): 202-206, 2020

\title{
Typification of two Linnaean names in Atriplex (Amaranthaceae sensu APG IV) referred to ancient Flora Anglica by Hudson and Linnaeus
}

\author{
Duilio Iamonico \\ Department of Biology, University of Pisa, 56126 Pisa, Italy
}

Corresponding author: Duilio Iamonico: d.iamonico@yahoo.it

This pdf constitutes the Version of Record published on $31^{\text {st }}$ August 2020

\begin{abstract}
The typification of the names Atriplex marina and $A$. maritima is discussed. $A$. marina is lectotypified on a Petiver's illustration and synonymised with $A$. littoralis (heterotypic synonym), whereas $A$. maritima is neotypified on a specimen from BM and synonymised with $A$. laciniata (homotypic synonym).
\end{abstract}

Keywords: Atriplex laciniata; Atriplex littoralis, Atriplex marina; Atriplex maritima; typification; nomenclature.

\section{Introduction}

Atriplex L. (Amaranthaceae Juss. s.l. sensu APG IV, 2016) is a genus comprising about 260 species, which are distributed in arid and semiarid regions of Eurasia, America and Australia (Akeroyd, 1993; Sukhorukov \& Danin, 2009; Kadereit et al., 2010; Brignone et al., 2016). According to Kadereit et al. (2010) this genus is monophyletic, including Obione Gaertn., Teutliopsis (Dumort.) Čelak. and some other segregate genera.

Linnaeus published 14 names under Atriplex (see Jarvis, 2007), of which just one ( $A$. portulacoides L.) currently belongs to another genus, i.e. Halimione Aellen (see e.g., Ball, 1993; Jarvis, 2007; Iamonico, 2017). Two out of these 14 Linnaean Atriplex names are not yet typified (see Jarvis, 2007) and are here discussed as part of an ongoing study of Linnaean names in Amaranthaceae s.l. (see also Iamonico, 2014, 2016; Iamonico \& Kadereit, 2013; Iamonico \& Jarvis, 2012; Iamonico et al., 2012; Iamonico \& Sukhorukov, 2014).

\section{Material and methods}

This research is based on the analysis of relevant literature (i.e. protologues of the names investigated and pre-Linnaean works therein cited, and primary Floras in which the studied names are listed) and examination of specimens preserved at BM and LINN (herbarium acronyms following Thiers, 2020 [continuously updated]). The articles cited throughout the text follow the Shenzen Code (Turland et al., 2018). 


\section{Typifications}

\section{Atriplex marina}

Linnaeus (1771: 300) described Atriplex marina providing a short diagnosis ("ATRIPLEX caule herbaceo, erecto, foliis linearibus serratis") which was taken directly from Hudson (1762: 377). In addition, Linnaeus (1771) cited two synonyms from Bauhin [1623: 152 ("Atriplex maritima angustifolia")], and Petiver (1713, "Atriplex angustifolia dentata"). The provenance ("Habitat in Angliae, Sveciae litoribus marinis") was also reported. Petiver (1713) published an illustration ("t. $7 \mathrm{f.} 4^{\prime \prime}$ ) which is part of the original material for the name Atriplex marina [also Hudson (1762), in his Flora Anglica, cited Petiver]. Note that, since Hudson (1762) validly published $A$. serrata, the name $A$. marina by Linnaeus (1771) appears as a replaced, superfluous and illegitimate name according to Arts. 52.1, and 52.2 of ICN. As a consequence, the type of the Linnaean's A. marina is that of Hudson's $A$. serrata.

No specimens which can be considered as part of the original material for Atriplex serrata ( $\equiv$ A. marina) can be found. As a consequence, Petiver's illustration appears to be the only extant element useful for the purpose of lectotypification. This image (Fig. 1) shows a complete plant with root, leaves, and inflorescences whose features match both Linnaean's and Hudson's descriptions, and it is here designated as the lectotype of Atriplex serrata. Although the bracteoles, which are of major taxonomic importance in Atriplex, are not visible in Petiver's illustration, it is clearly identifiable as $A$. littoralis according to the current concept in Atriplex (e.g., Akeroyd, 1993; Sukhorukov, 2006; Sukhorukov \& Danin 2009; Iamonico, 2017).

Atriplex littoralis L., Sp. PI. 2: 1054. 1753. - TYPE (lectotype designated by Jonsell \& Jarvis, 1994: 154): Herb. Linnaeus No. 1221.22 (LINN!). - An image of the lectotype is available at http://linnean-online.org/10781/

= Atriplex serrata Huds., Fl. Angl.: 377. $1762 \equiv$ A. marina L., Mant. Pl. Alt.: 300. 1771, nom. superfl. et illeg. (Arts. 52.1, and 52.2 of ICN) - TYPE (lectotype designated here): [Icon] Atriplex angustifolia dentata in Petiver (1713: t. 7, f. 4). - For an image of the lectotype see Fig. 1.

\section{Atriplex maritima}

Atriplex maritima L. was published in the Linnaean edition of Flora Anglica (Linnaeus, 1754) where the name was validated by a mere reference to the species numbered "152-8" in the third edition of Ray's Synopsis Methodica Stirpium Britannicarum (1724: 152-153).

Ray (1724: 152) reported as synonyms of his "Atriplex maritima" a polynomial by Bauhin (1623: 120, "[Atriplex] maritima laciniata") which was, in turn, considered by Linnaeus (1753: 1053) as a synonym of Atriplex laciniata L. in the first edition of Species Plantarum. Linnaeus (1762: 1493) again listed Bauhin's polynomial as a synonym of $A$. laciniata, whereas the name $A$. maritima was not included. It seems that Linnaeus $(1753,1762)$ changed his opinion about the originally described species $A$. maritima and he later included 
it in $A$. laciniata. Stearn (1973: 64), in fact, treated the Linnaean $A$. maritima as a synonym of $A$. laciniata, and I agree with this consideration.

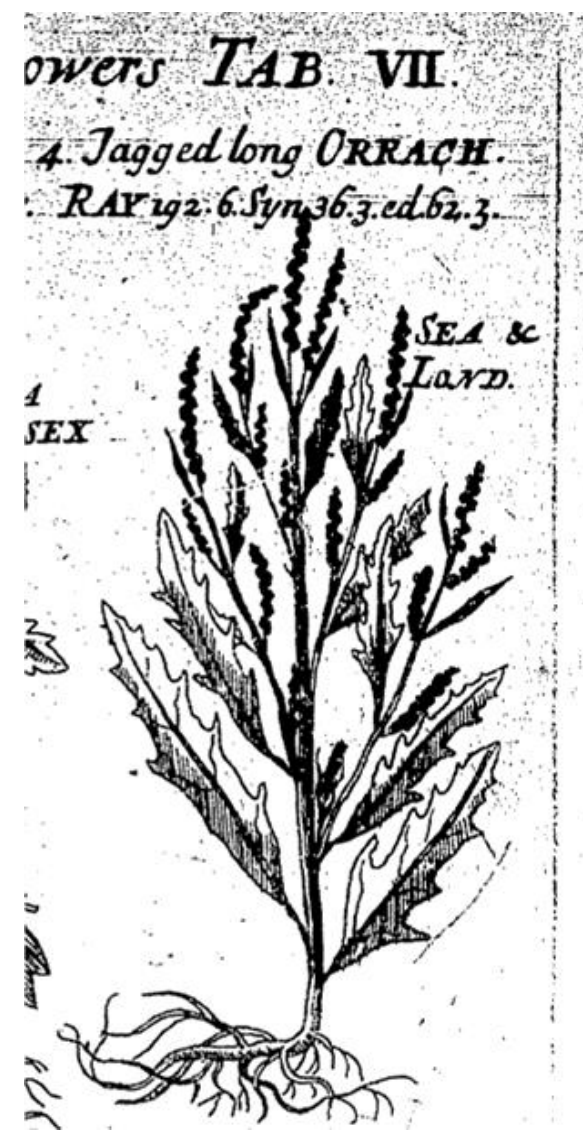

Figure 1. Lectotype of the name Atriplex serrata ( $\equiv$ A. marina) (Petiver's illustration).

Since no original material was traced in the Linnaean and Linnaean-linked herbaria (see also Jarvis, 2007), a neotypification is required according to Art. 9.7 of ICN. Here I propose to designate as the neotype of the name Atriplex maritima, the lectotype of $A$. laciniata (BM000647540) which was correctly proposed by Taschereau (1972: 1591). As a consequence, the Linnaean $A$. maritima is here considered as homotypic synonym of $A$. laciniata.

Atriplex laciniata L., Sp. Pl. 2: 1053. 1753. - TYPE (lectotype designated by Taschereau, 1972: 1591) Herb. Clifford: 469, Atriplex 3 (BM000647540!). An image of the lectotype is available at https://www.nhm.ac.uk/resources/research-curation/projects/cliffordherbarium/lgimages/BM000647540.JPG

= Atriplex maritima L., Fl. Angl.: 25. 1754 - TYPE (neotype designated here): Herb. Clifford: 469, Atriplex 3 (BM000647540!).

\section{Acknowledgements}

Thanks are due to the Directors and Curators of all the herbaria quoted in this paper for their support during our visits or loan of specimens/photographs, and to W. Kocher (Library of the University of Bern) for sending me an image of 
Petiver's illustration from Herbarii Britannici. A. Sukhorukov (Moscow State University) and helping me in the identification of Petiver's illustration.

\section{References}

Akeroyd, J.R. 1993. Atriplex L. In: Tutin, T.G., Burges, N.A., Chater, A.O., Edmonson, J.R., Heywood, V.H., Moore, D.M., Valentine, D.H., Walters, S.M. \& Webb, D.A. eds., Flora Europaea $2^{\text {nd }}$ ed., 1: $115-177$. Cambridge: Cambridge University Press.

APG IV 2016. An update of the Angiosperm Phylogeny Group classification for the orders and families of flowering plants: APG IV. Botanical Journal of Linnean Society 181: 1-20.

Ball, P.W. 1993. Halimione Aellen. In: Tutin, T.G., Burges, N.A., Chater, A.O., Edmonson, J.R., Heywood, V.H., Moore, D.M., Valentine, D.H., Walters, S.M. \& Webb, D.A. eds., Flora Europaea $2^{\text {nd }}$ ed., 1: 117. Cambridge: Cambridge University Press.

Bauhin, C. 1623. Pinax theatri botanici. Basileae: sumptibus \& typis Ludovici Regis.

Brignone, N.F., Denham, S.S. \& Pozner, R. 2016. Synopsis of the genus Atriplex (Amaranthaceae, Chenopodioideae) for South America. Australian Systematic Botany 29: 324-357. http://doi.org/10.1071/SB16026

Hudson, G. 1762. Flora Anglica. Londinii: Impensis auctoris.

Iamonico, D. 2014. Lectotypification of Linnaean names in the genus Achyranthes L. (Amaranthaceae). Taxon 63: 405-407. http://dx.doi.org/10.12705/632.2

Iamonico, D. 2016. Nomenclature survey of the genus Amaranthus (Amaranthaceae). 3. Names linked to the Italian flora. Plant Biosystems 150(3): 519-531. http://dx.doi.org/10.1080/11263504.2014.987188

Iamonico, D. 2017. Atriplex L. In: Pignatti, S., ed., Flora D'Italia $2^{\text {nd }}$ ed., 2: $250-$ 256. Bologna: Edagricole.

Iamonico, D. \& Jarvis, C.E. 2012. Lectotypification of two Linnaean names in Chenopodium L. (Amaranthaceae). Taxon 61(3): 864-865.

Iamonico, D. \& Kadereit, G. 2013. Typification of the name Kochia saxicola (Chenopodiaceae). Novon 22(4): 418-421.

http://dx.doi.org/10.3417/2011058

Iamonico, D. \& Sukhorukov, A.P. 2014. Studies on the genus Atriplex (Chenopodiaceae) in Italy. VI. Names by Michele Tenore: Atriplex axillaris, A. diffusa, and $A$. polysperma. Hacquetia 13(2): 285-296. 10.2478/hacq2014-0005.

Iamonico, D., Sukhorukov, A.P. \& Jarvis, C.E. 2012. Lectotypification of the Linnaean name Anabasis foliosa L. (Chenopodiaceae). Taxon 61(5): 11031104.

Jarvis, C. 2007. Order out of Chaos: Linnaean Plant Names and Their Types. London: Linnean Society of London and the Natural History Museum.

Jonsell, B. \& Jarvis, C. 1994. Lectotypifications of Linnaean names for Flora Nordica Vol. 1 (Lycopodiaceae-Papaveraceae). Nordic Journal of Botany 14(2): 145-164. 
Kadereit, G., Mavrodiev, E.V., Zacharias, E.H. \&, Sukhorukov, A. P. 2010. Molecular phylogeny of Atripliceae (Chenopodioideae, Chenopodiaceae): Implications for systematics, biogeography, flower and fruit evolution, and the origin of C4 photosynthesis. American Journal of Botany 97(10): 1664-1687.

Linnaeus, C. 1753. Species plantarum, 2. Holmiae: Laurentii Salvii.

Linnaeus, C. 1754. Flora Anglica. Upsaliae: Laur. Magnus Hojer, Reg. Acad. Typogr.

Linnaeus, C. 1762. Species Plantarum ed. 2, 1. Stockholmiae: Laurentii Salvii. Linnaeus, C. 1771. Mantissa plantarum altera. Stockholm: Laurentius Salvius. Petiver, J. 1713. Herbarii Britannici clariss. D. Raii catalogus Cum iconibus ad vivum delineatis, \& ære incisis; in folio. Quibus adjunguntur singulorum nomina, summa cum are sculpta simul cum locis indigenis, tempore folrendi, coloribus florum, notis sec annuis, seu perennibus, vulgaribus, vel raris, cum floribus, seminibus, corumque vasculis, ab ipsis plantis figuratis \& singulis sepciebus annexis. London: Verlag nicht ermittelbar.

Ray, J. 1724. Synopsis Methodica Stirpium Britannicarum, $3^{\text {th }}$ ed. Londini: Impensis Gulielmi \& Joannis Innys Regiae Societatis Typographorum.

Stearn, W.T. 1973. Ray, Dillenius, and the Synopsis methodica Stirpium Britannicarum. London: The Ray Society.

Sukhorukov, A.P. 2006. Zur Systematik und Chorologie der in Russland und benachbarten Staaten (in den Grenzen der ehemaligen UdSSR) vorkommenden Atriplex-Arten (Chenopodiaceae). Annalen des Naturhistorischen Museums in Wien 108B: 307-420.

Sukhorukov, A.P. \& Danin, A. 2009. Taxonomic notes on Atriplex sect. Teutliopsis and sect. Atriplex in Israel and Syria. Flora Mediterranea 19: 15-23.

Taschereau, P.M. 1972. Taxonomy and distribution of Atriplex species in Nova Scotia. Canadian Journal of Botany 50: 1571-1594.

Thiers, B. 2020 [continuously update]. Index Herbariorum: A global directory of public herbaria and associated staff. New York Botanical Garden's Virtual Herbarium. [accessed 22 June 2019]. Available at: $<$ http://sweetgum.nybg.org/ih/>.

Turland, N.J., Wiersema, J.H., Barrie, F.R., Greuter, W., Hawksworth, D.L., Herendeen, P.S., Knapp, S., Kusber, W.-H., Li, D.-Z., Marhold, K., May, T.W., McNeill, J., Monro, A.M., Prado, J., Price, M.J. \& Smith, G.F. (eds.) 2018. International Code of Nomenclature for algae, fungi, and plants (Shenzhen Code). adopted by the Nineteenth International Botanical Congress, Shenzhen, China, July 2017. Regnum Vegetabile 159: 1-254.

Copyright retained by author(s). Published by BSBI under the terms of the Creative Commons Attribution 4.0 International Public License.

ISSN: $2632-4970$

https://doi.org/10.33928/bib.2020.02.202 